\title{
Relating Fish Hg to Variations in Sediment Hg, Climate and Atmospheric Deposition
}

\author{
Mina Nasr, Paul A. Arp \\ Faculty of Forestry and Environmental Management, University of New Brunswick, Fredericton, Canada \\ Email: arp1@unb.ca
}

How to cite this paper: Nasr, M. and Arp, P.A. (2018) Relating Fish Hg to Variations in Sediment $\mathrm{Hg}$, Climate and Atmospheric Deposition. American Journal of Climate Change, 7, 402-419.

https://doi.org/10.4236/ajcc.2018.73024

Received: April 19, 2108

Accepted: August 14, 2018

Published: August 17, 2018

Copyright (c) 2018 by authors and Scientific Research Publishing Inc. This work is licensed under the Creative Commons Attribution International License (CC BY 4.0).

http://creativecommons.org/licenses/by/4.0/ (c) () Open Access

\begin{abstract}
This article addresses total fish $\mathrm{Hg}$ concentrations ( $\mathrm{THg}$ ) by variations in lake Sediment $\mathrm{THg}$, atmospheric $\mathrm{Hg}$ deposition ( $\operatorname{atmHg} \mathrm{dep}_{\text {), }}$ and climate, i.e., mean annual precipitation (ppt) and air temperature. The Fish THg data were taken from the 1967-to-2010 Fish Mercury Datalayer (FIMDAC). This compilation was standardized for $12-\mathrm{cm}$ long Yellow Perch in accordance with the USGS National Descriptive Model for Mercury in Fish (NDMMF [1]), and documents Fish THg across 1936 non-contaminated lakes in Canada. About $40 \%$ of the standardized Fish $\mathrm{THg}$ variations related positively to increasing ppt and Sediment $\mathrm{THg}$, but negatively to increasing mean annual July temperature $\left(\mathrm{T}_{\text {July }}\right)$. Only $20 \%$ of the Fish $\mathrm{THg}$

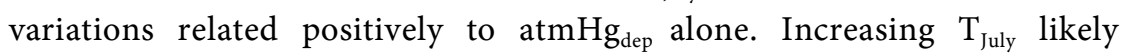
influences Fish $\mathrm{Hg}$ through increased lake and upslope $\mathrm{Hg}$ volatilization, in-fish growth dilution, and temperature-induced demethylization. FIMDAC Fish $\mathrm{THg}$ effectively did not change over time while atmHg $\mathrm{g}_{\text {dep }}$ decreased. Similarly, the above Fish $\mathrm{Hg}$ trends would likely not change much based on projecting the above observations into the future using current 2070 climate-change projections across Canada and the continental US. Regionally, the projected changes in Fish $\mathrm{Hg}$ would mostly increase with increasing ppt. Additional not-yet mapped increases are expected to occur in subarctic regions subject to increasing permafrost decline. Locally, Fish THg would continue to be affected by upwind and upslope pollution sources, and by lake-by-lake changes in water aeration and rates of lake-water inversions.
\end{abstract}

\section{Keywords}

Total Hg Concentrations, Fish, Sediments, Atmospheric Hg Deposition, Precipitation, Air Temperature, Climate-Change Projections, North America 


\section{Introduction}

There is much uncertainty about how climate and atmospheric $\mathrm{Hg}$ deposition affect Fish THg [2] [3] [4] [5]. In part, this uncertainty is due to large and yet to be quantified land-to-lake and in-lake variations by which Hg uptake by fish increases or decreases. The primary concern is that the bioaccumulation of toxic methyl $\mathrm{Hg}(\mathrm{MeHg})$ in fish and other aquatic organisms may increase with increasing atmospheric $\mathrm{Hg}$ deposition and climate warming. In principle, the presence and accumulation of $\mathrm{Hg}$ and $\mathrm{MeHg}$ in fish and sediments starts with the sequestration of atmospheric $\mathrm{Hg}$ deposition on land and water, and with the release of surface-exposed geogenic $\mathrm{Hg}$ minerals. A part of land-retained $\mathrm{Hg}$ is gradually released into streams and lakes through 1) direct $\mathrm{Hg}$-containing litter inputs (detritus), 2) upslope soil and stream bank erosion, and 3) transfer of $\mathrm{Hg}$ bound by water-carried particulate and dissolved Hg-containing matter [6] [7] [8] [9]. With regard to detrital Hg inputs, tree foliage, twigs, branches, bark, and wood generally have lower $\mathrm{Hg}$ concentrations than mosses, fungi, and lichens [10] [11]. In soils, THg decreases from the organic litter layers on the surface to the subsoil layers below [10]. In downstream, the total amount of Hg generally increases with increasing organic matter transfer [12], which in turn leads to increasing Hg accumulations in stream and lake sediments [13] [14] [15] [16]. Due to particulate $\mathrm{Hg}$ retention in wet areas and wetlands, first-order stream and lake sediments downslope from forested and wetland dominated watersheds have higher THg and organic matter contents than elsewhere [17]-[22].

Within lakes, $\mathrm{Hg}$ accumulation in sediments and trophic $\mathrm{Hg}$ bioaccumulation depend on many physical and chemical conditions and their combined effects on biological processes [17] [23] [24] [25] [26] [27]. For example, physical and chemical properties of water (e.g., temperature, aeration, $\mathrm{pH}$, color, organic matter, and suspended mineralcontent) all influence the fate of $\mathrm{Hg}$ with regard to biological uptake, re-precipitation and settling, methylation, demethylation, and volatilization [28] [29] [30]. From a simplifying perspective, total Hg concentrations in water, sediments andaquatic organism are co-variants [13] [22] [31] [32] [33].

This article focuses on analyzing the extent to which standardized data for total Hg concentrations ( $\mathrm{THg}$ ) in fish-as compiled within the Fish Mercury Datalayer (FIMDAC [1]) - co-vary with lake Sediment THg, atmospheric Hg deposition $\left(\operatorname{atmHg}_{\text {dep }}\right)$, mean annual precipitation (ppt), and mean annual air temperatures for January (winter, $\mathrm{T}_{\text {Jan }}$ ) and July (summer, $\mathrm{T}_{\text {July }}$ ). This analysis was enabled by cross-referencing the Fish THg data to the modelled and mapped Sediment $\mathrm{THg}$, atmHg $\mathrm{dep}_{\text {dep }}$ ppt, $\mathrm{T}_{\text {Jan }}$ and $\mathrm{T}_{\text {July }}$ variations across Canada, with special reference to potential climate-induced changes up to 2070. The hypothesis is that at least some of the Fish THg variations can be quantified in this way for tentative trend mapping across Canada, the continental USA, and over time. Data pertaining to lakes downwind and downslope from major anthropogenic 
Hg release locations (e.g. [34]) are not part of this analysis.

\section{Methods}

The 1967 to 2010 FIMDAC Fish THg data (reported in ng. $\mathrm{g}^{-1}$, wet-weight) were compiled for 1936 pristine lakes across Canada from 1967 to 2010. These data were standardized for one fish species (Yellow Perch) and one fork length $(12 \mathrm{~cm})$, done in accordance with USGS National Descriptive Model for Mercury in Fish (NDMMF [1] [35] [36] [37]). Fish sampling per lake varied from one time to multiple times. Total sample size used for the analysis below was $n=3179$. Fish THg data from water bodies other than lakes were not included; also excluded: Fish $\mathrm{THg} \leq 1 \mathrm{ug} / \mathrm{g}$.

The data for lake Sediment THg (in $\mathrm{ng}^{\mathrm{g}} \mathrm{g}^{-1}$ ) were obtained from the open geochemical survey files of the Geological Survey of Canada [38] [39], and were compiled for the provinces of Quebec and Nova Scotia as well [40]. This compilation produced 147,910 THg one-time sampling points per lake, all based on 30-cm deep sediment cores collected, dried, sieved, and analyzed from 1960 to 2008. The resulting Sediment THg data were averaged per National Topographic System (NTS) tile (1:50,000 scale [41]).

The data layers for atmHg $g_{\text {dep}}$, ppt, $\mathrm{T}_{\text {Jan }}$ and $\mathrm{T}_{\text {July }}$ (shown and contoured in Figure 1) were obtained as follows:

1) total net wet and dry atmHg $g_{\text {dep }}$, in $\mu \mathrm{g} \cdot \mathrm{m}^{-2} \cdot \mathrm{a}^{-1}$, from the Global/Regional Atmospheric Heavy Metals Model (GRAHM), at $25 \times 25 \mathrm{~km}^{2}$ grid resolution, Canada only [42].

2) ppt (in $\mathrm{m}$ ), and $\mathrm{T}_{\text {July }}$ and $\mathrm{T}_{\text {Jan }}$ (in ${ }^{\circ} \mathrm{C}$ ) for Canada and the USA, from the Coupled Model Intercomparison Project (CMIP5 [43]), Scenario rcp8.5, downloaded for 2011 and 2070

(http://climate-scenarios.canada.ca/?page=download-intro).

With ArcMap, cross-referencing was done by data-layer extracting the lake Sediment $\mathrm{THg}$, atmHg dep , ppt, $\mathrm{T}_{\text {Jan }}$ and $\mathrm{T}_{\text {July }}$ values for each FIMDAC Fish THg location, row-by-row. This was followed by multivariate regression and factor analysis, with Fish THg, Sediment THg, atmHg dep, ppt, $\mathrm{T}_{\text {July }}$ and $\mathrm{T}_{\text {Jan }}$ as variables.

\section{Results}

Table 1 provides a basic statistical summary of the variables used in this article. Most notably, these variables differ across Canada in range, such that the lake-by-lake entries for Fish THg have a wider maximum to minimum ratio (i.e. 38) than the corresponding model-derived entries for Sediment THg (i.e.

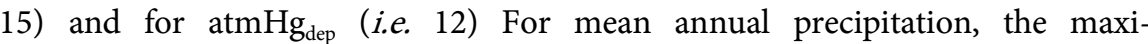
mum/minimum ratio is 20 . Mean annual $\mathrm{T}_{\text {Jan }}$ is about three times more variable than mean annual $\mathrm{T}_{\text {July }}$. The longitudinal range is 4 times larger than the latitudinal range.

Using Sediment $\mathrm{THg}$ as dependent variable, and atmHg $\mathrm{g}_{\text {dep }}$, ppt, $\mathrm{T}_{\text {Jan }}$ and $\mathrm{T}_{\text {July }}$ as independent variables produced: 


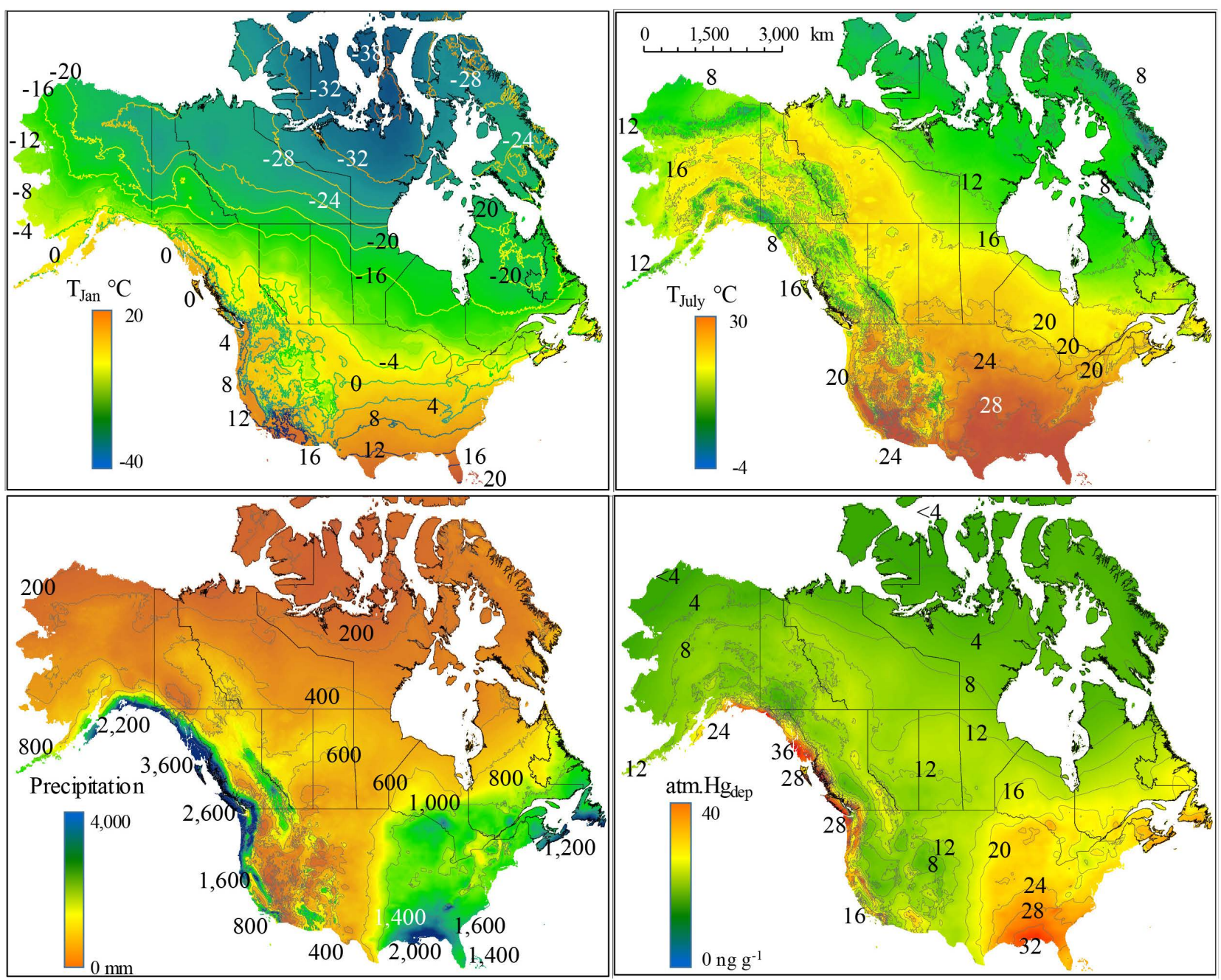

Figure 1. Mean annual January and July air temperature $\left(\mathrm{T}_{\text {Ian }}, \mathrm{T}_{\text {July }}\right)$ and mean annual precipitation (ppt) according to the Coupled Model Intercomparison Project (CMIP5-rcp8.5) at http://climate-scenarios.canada.ca/?page=download-intro with contours. Also shown: mean annual net atmospheric $\mathrm{Hg}$ deposition $\left(\mathrm{atmHg}_{\mathrm{dep}}\right.$ ), based on the Global/Regional Atmospheric Heavy Metals Model (GRAHM2005). Extent: across Canada (provinces and northern territories outlined except most northern parts) and the continental USA.

Table 1. Basic statistics concerning the variables in Equations (1) to (8); Fish THg > $10 \mathrm{ppb} ; \mathrm{n}=3179$.

\begin{tabular}{|c|c|c|c|c|c|}
\hline Variable & Units & Mean & Std. Dev. & Minimum & Maximum \\
\hline Fish $\log _{10} \mathrm{THg}$ & $\log _{10}\left(\mathrm{ng} \cdot \mathrm{g}^{-1}\right)$, wet weight & 1.81 & 0.30 & 1.30 & 2.88 \\
\hline Lake $\log _{10} \mathrm{THg}$ (modelled) & $\log _{10}\left(n g \cdot g^{-1}\right)$, dry weight & 1.76 & 0.15 & 1.54 & 2.72 \\
\hline Precipitation & $\mathrm{m} \cdot \mathrm{a}^{-1}$ & 0.65 & 0.30 & 0.14 & 2.81 \\
\hline $\operatorname{atmHg}_{\text {dep }}$ & $\mu \mathrm{g} \cdot \mathrm{m}^{-2} \cdot \mathrm{a}^{-1}$ & 11.3 & 4.5 & 2.5 & 31.1 \\
\hline $\mathrm{T}_{\text {July }}$ & ${ }^{\circ} \mathrm{C}$ & 16.6 & 1.8 & 6.2 & 20.9 \\
\hline $\mathrm{T}_{\text {Jan }}$ & ${ }^{\circ} \mathrm{C}$ & -19.6 & 5.8 & -33.0 & 4.6 \\
\hline Latitude & Degrees & 53.4 & 4.6 & 43.9 & 69.4 \\
\hline Longitude & Degrees & -93.9 & 17.0 & -138.7 & -53.8 \\
\hline
\end{tabular}


Sediment $\log _{10} \mathrm{THg}$

$$
\begin{aligned}
= & (1.380 \pm 0.048)+(0.406 \pm 0.059) \mathrm{ppt} \\
& +(0.012 \pm 0.004) \mathrm{atmHg}_{\text {dep }}, R^{2}=0.432
\end{aligned}
$$

with ppt and atm $\mathrm{THg}_{\text {dep }}$ as significant predictor variables.

Regressing Fish $\log _{10} \mathrm{THg}$ versus Sediment $\mathrm{THg}$, atmHg $\mathrm{g}_{\text {dep }}$, ppt, $\mathrm{T}_{\text {July }}$, and $\mathrm{T}_{\text {Jan }}$ per lakegenerated the following regression equation:

Fish $\log _{10} \mathrm{THg}$

$=(1.32 \pm 0.02)$ Sediment $\log _{10} \mathrm{THg}-(0.031 \pm 0.002) \mathrm{T}_{\text {July }}, R^{2}=0.382$

By climate variables alone, the following was obtained:

Fish $\log _{10} \mathrm{THg}$

$$
\begin{aligned}
= & (1.54 \pm 0.07)+(0.77 \pm 0.02) p p t-(0.022 \pm 0.003) \mathrm{T}_{\text {July }} \\
& -(0.007 \pm 0.001) \mathrm{T}_{\mathrm{Jan}}, R^{2}=0.385
\end{aligned}
$$

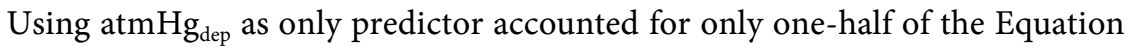
(2) and (3) captured fish $\log _{10} \mathrm{THg}$ variations:

Fish $\log _{10} \mathrm{THg}=(1.47 \pm 0.01)+(0.030 \pm 0.001) \mathrm{atmHg}_{\text {dep }}, R^{2}=0.206$

Using Sediment THg and ppt each as only fish $\log _{10} \mathrm{THg}$ predictors yielded:

Fish $\log _{10} \mathrm{THg}=(1.02 \pm 0.03)$ Sediment $\log _{10} \mathrm{THg}, R^{2}=0.342$

and

Fish $\log _{10} \mathrm{THg}=(1.42 \pm 0.01)+(0.60 \pm 0.01) \mathrm{ppt}, R^{2}=0.354$

thereby accounting for about $90 \%$ of the variations captured by Equations (2) and (3). Using atmHg dep, $\mathrm{T}_{\text {July }}$ and $\mathrm{T}_{\text {Jan }}$ as predictor variables produced

Fish $\log _{10} \mathrm{THg}$

$$
\begin{aligned}
= & (2.67 \pm 0.06)+(0.025 \pm 0.001) \mathrm{atmHg}_{\text {dep }} \\
& -(0.050 \pm 0.003) \mathrm{T}_{\text {July }}+(0.016 \pm 0.01) \mathrm{T}_{\text {Jan }}, R^{2}=0.303
\end{aligned}
$$

Hence, using atmHg dep together with $\mathrm{T}_{\text {July }}$ and $\mathrm{T}_{\text {Jan }}$ improved the results, but using Sediment $\log _{10} \mathrm{THg}$ or ppt with and without $\mathrm{T}_{\text {July }}$ as additional predictor variables was more effective in capturing more of the Fish $\log _{10} \mathrm{THg}$ variations (Equations (2), (3), and (6), (7)). In noting that $80 \%$ of the GRAHM2005-modelled atmHg $g_{\text {dep }}$ variations can also be attributed to climatic and geographic variations via Equation (8), i.e.,

$$
\begin{aligned}
\operatorname{atmHg}_{\text {dep }}= & -(24.7 \pm 0.8)+(26.8 \pm 1.0) \mathrm{ppt}^{0.5} \\
& +(0.80 \pm 0.06) \mathrm{T}_{\text {July }}(0.25 \pm 0.03) \mathrm{T}_{\text {Jan }}-(7.7 \pm 0.7) \text { Pacific Rim } \\
& +(7.5 \pm 1.0) \text { High Arctic Coastal Areas, } R^{2}=0.803
\end{aligned}
$$

it follows that climate and geography affect Fish THg, Sediment THg and atmospheric $\mathrm{Hg}$ in quantitatively and quantitatively different ways. For example, the positive effect of increasing ppt on atmHg $g_{\text {dep }}$ levels off with increasing ppt. The $\mathrm{T}_{\text {July }}$ effect on atmHg $\mathrm{dep}_{\text {dep }}$ is most likely a surrogate for the geographic $\mathrm{Hg}$ 
emission and subsequent $\mathrm{Hg}$ deposition pattern, which is highest along the southeastern USA-Canada border, and least for the snow- and ice-covered alpine and arctic areas. $\mathrm{T}_{\text {Jan }}$ likely accounts for increased $\mathrm{Hg}$ volatilities from snow-and ice-covered surfaces.

The location-specific adjustments for the Pacific Rim and High-Arctic coastal areas in Equation (8) can be used to compensate 1) for the ppt-induced atmHg $\mathrm{Hep}_{\text {dep }}$ dilution, and 2) for the $\mathrm{T}_{\mathrm{Jan}}$-induced underestimation for at $\mathrm{mHg}_{\mathrm{dep}}$ along the arctic coastlines, where oceanic $\mathrm{Hg}$ upwelling contributes to land-based and aquatic Hg sequestration and bioaccumulation [44] [45]. With respect to Fish THg, increases in ppt and Sediment THg affect Fish $\log _{10} \mathrm{THg}$ in direct proportions. Checking the correlations among the Equation (1) to (8) variables reveals that $\mathrm{T}_{\text {July }}$ only has a weak direct effect on Fish $\log _{10} \mathrm{THg}$ (Table 2). Nevertheless, factor analyzing this matrix revealed that $\mathrm{T}_{\text {July }}$ is an important negative co-variant of Fish $\log _{10} \mathrm{THg}$ as per factor 2 in Table 3.

Projecting the Equation (2) results across Canada and overlaying the Fish THg data produced the map in Figure 2 and the corresponding map-to-data residual conformance plot in Figure 3. According to Figure 3, about $80 \%$ of the standardized Fish THg variations conform to the Equation (2) projections within a factor of two, 8 times out of 10. In comparison, about $90 \%$ of the recorded lake Sediment THg variations conform to the Equation (1) projections within a factor of two, 8 times out of 10. This indicates that Fish THg is somewhat less predictable than Sediment THg, likely due to lake-specific factors that affect Fish $\mathrm{Hg}$ uptake and retention, such as, e.g., lake-to-lake variations in biogeochemical composition and trophic Hg uptake dynamics [46] [47].

Table 2. Correlation coefficients for the variables in Equations (1) to (6).

\begin{tabular}{|c|c|c|c|c|c|}
\hline Dependent variable & $\begin{array}{c}\text { Independent } \\
\text { variable }\end{array}$ & $\begin{array}{c}\text { Correlation } \\
\text { coefficient }\end{array}$ & 95\% Lower & 95\% Upper & P-Value \\
\hline \multirow{5}{*}{ Fish $\log _{10} \mathrm{THg}$} & Lake $\log _{10} \mathrm{THg}$ & 0.588 & 0.565 & 0.611 & $<0.0001$ \\
\hline & $\mathrm{T}_{\text {July }}$ & -0.035 & -0.070 & 0.000 & 0.049 \\
\hline & $\mathrm{T}_{\text {January }}$ & 0.382 & 0.352 & 0.412 & $<0.0001$ \\
\hline & atmHg $g_{\text {dep }}$ & 0.454 & 0.426 & 0.481 & $<0.0001$ \\
\hline & Precipitation & 0.595 & 0.572 & 0.617 & $<0.0001$ \\
\hline \multirow{4}{*}{ Lake $\log _{10} \mathrm{THg}$} & $\mathrm{T}_{\text {July }}$ & 0.251 & 0.218 & 0.283 & $<0.0001$ \\
\hline & $\mathrm{T}_{\text {January }}$ & 0.764 & 0.750 & 0.779 & $<0.0001$ \\
\hline & atmHg $\mathrm{dep}$ & 0.847 & 0.837 & 0.857 & $<.0001$ \\
\hline & Precipitation & 0.984 & 0.983 & 0.985 & $<0.0001$ \\
\hline \multirow{3}{*}{$\mathrm{T}_{\text {July }}$} & $\mathrm{T}_{\text {January }}$ & 0.462 & 0.434 & 0.489 & $<0.0001$ \\
\hline & atmHg $g_{\text {dep }}$ & 0.318 & 0.287 & 0.349 & $<0.0001$ \\
\hline & Precipitation & 0.211 & 0.178 & 0.244 & $<0.0001$ \\
\hline \multirow{2}{*}{$\mathrm{T}_{\mathrm{jan}}$} & atmHg $g_{\text {dep }}$ & 0.545 & 0.521 & 0.569 & $<0.0001$ \\
\hline & Precipitation & 0.788 & 0.775 & 0.801 & $<0.0001$ \\
\hline atmHg $g_{\text {dep }}$ & Precipitation & 0.744 & 0.728 & 0.759 & $<0.0001$ \\
\hline
\end{tabular}


Table 3. Factor analysis of the correlations among the Equations (1) to (6) variables, with additional reference to latitude and longitude.

\begin{tabular}{cccc}
\hline Variable & Factor 1 & Factor 2 & Communality \\
\hline Fish $\log _{10} \mathrm{THg}$ & $\mathbf{0 . 6 4}$ & $\mathbf{0 . 4 7}$ & 0.63 \\
Lake $\log _{10} \mathrm{THg}$ & $\mathbf{0 . 9 7}$ & 0.09 & 0.95 \\
Precipitation & $\mathbf{0 . 9 5}$ & 0.11 & 0.92 \\
atmHg ${ }_{\text {dep }}$ & $\mathbf{0 . 8 4}$ & 0.00 & 0.70 \\
$\mathrm{~T}_{\text {jan }}$ & $\mathbf{0 . 8 1}$ & -0.32 & 0.76 \\
$\mathrm{~T}_{\text {July }}$ & 0.38 & $-\mathbf{0 . 8 6}$ & 0.88 \\
Latitude & $\mathbf{0 . 9 2}$ & 0.25 & 0.91 \\
Longitude & $\mathbf{0 . 8 0}$ & 0.40 & 0.80 \\
\hline
\end{tabular}

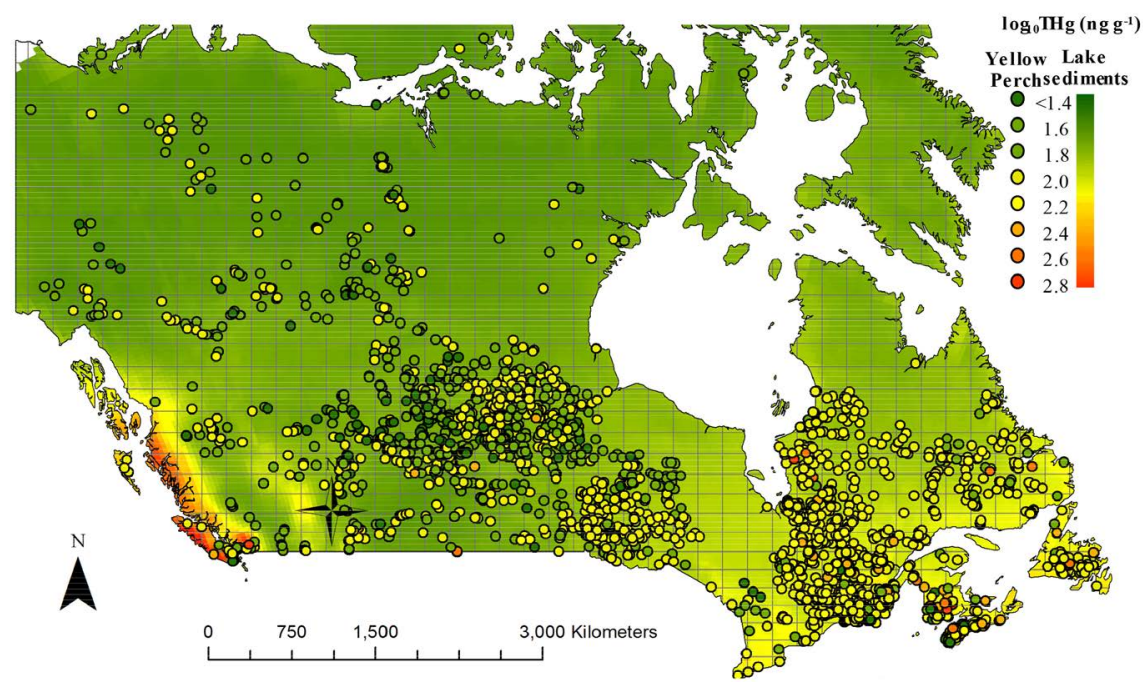

Figure 2. Overlaying FIMDAC locations and standardized Fish THg concentrations (Yellow Perch, wet weight basis, 12-cm long) on the corresponding Equation (2) generated map, using map-projected lake Sediment THg (ng. $\mathrm{g}^{-1}$ ) and mean annual July temperature $\left({ }^{\circ} \mathrm{C}\right)$ as only projection variables. Also shown: NTS tile grid.

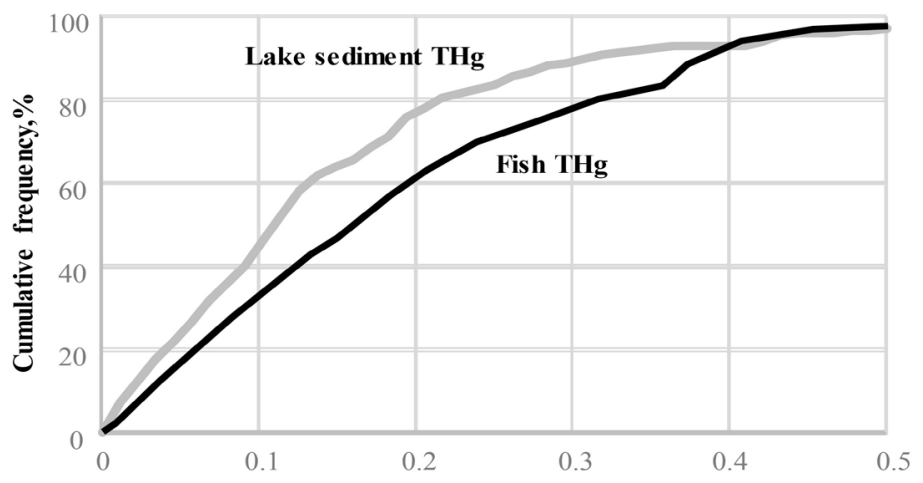

Best-fitted absolute residuals for fish and lake sediment $\log _{10} \mathrm{THg}\left(\mathrm{ng} \mathrm{g}^{-1}\right)$

Figure 3. Standardized fish and lake sediment $\log _{10}$ THg map-to-data conformance plot based on Equations (1) and (2); x-axis: best-fitted absolute residuals for fish and lake sediment $\log _{10} \mathrm{THg}\left(\mathrm{ng}^{\mathrm{g}} \mathrm{g}^{-1}\right)$; y-axis: cumulative frequency of the $\log _{10} \mathrm{THg}$ residuals. 
Using Equations (1), (2) and (8) produced the Sediment THg, Fish THg, and atmHg $g_{\text {dep }}$ projections in Figure 4 across all of Canada and the continental USA for current conditions. To what extent these projections require further data calibrations needs to be determined. This includes analyzing forthcoming total dry atmospheric $\mathrm{Hg}$ deposition and $\mathrm{Hg}$ in forest litter data and maps from the Mercury Deposition Network (MDN; http://nadp.sws.uiuc.edu/mdn/). At this stage, the Equations (8)-projected pattern in Figure 4 resembles USA maps for wet $\mathrm{Hg}$ deposition in general, with highest $\mathrm{Hg}$ deposition occurring along the south-eastern States, low deposition rates for the mid-eastern States, and increased deposition along the southern Pacific coast of Alaska. Currently available data on dry deposition [48] [49] increase the wet deposition pattern by a factor of 2, as is the case for the GRAHM-based net atmTH $\mathrm{H}_{\text {dep }}$ projections via Equations (8). This was also the case for the earlier North American Hg deposition study by [50] and [51].

\section{Discussion}

The above results account for about $40 \%$ of the standardized $\mathrm{Hg}$ concentrations in fish, with Sediment $\mathrm{THg}$, atm $\mathrm{THg}_{\text {dep }}, \mathrm{ppt}, \mathrm{T}_{\text {July, and }} \mathrm{T}_{\text {Jan }}$ as significant co-variants in varying combinations. The co-varying influences on Fish THg are particularly strong for Sediment $\mathrm{THg}$ and ppt, likely due to direct and indirect precipitation-induced $\mathrm{Hg}$ inputs into lake water from the atmosphere and surrounding land. While these inputs would have the most direct and causative

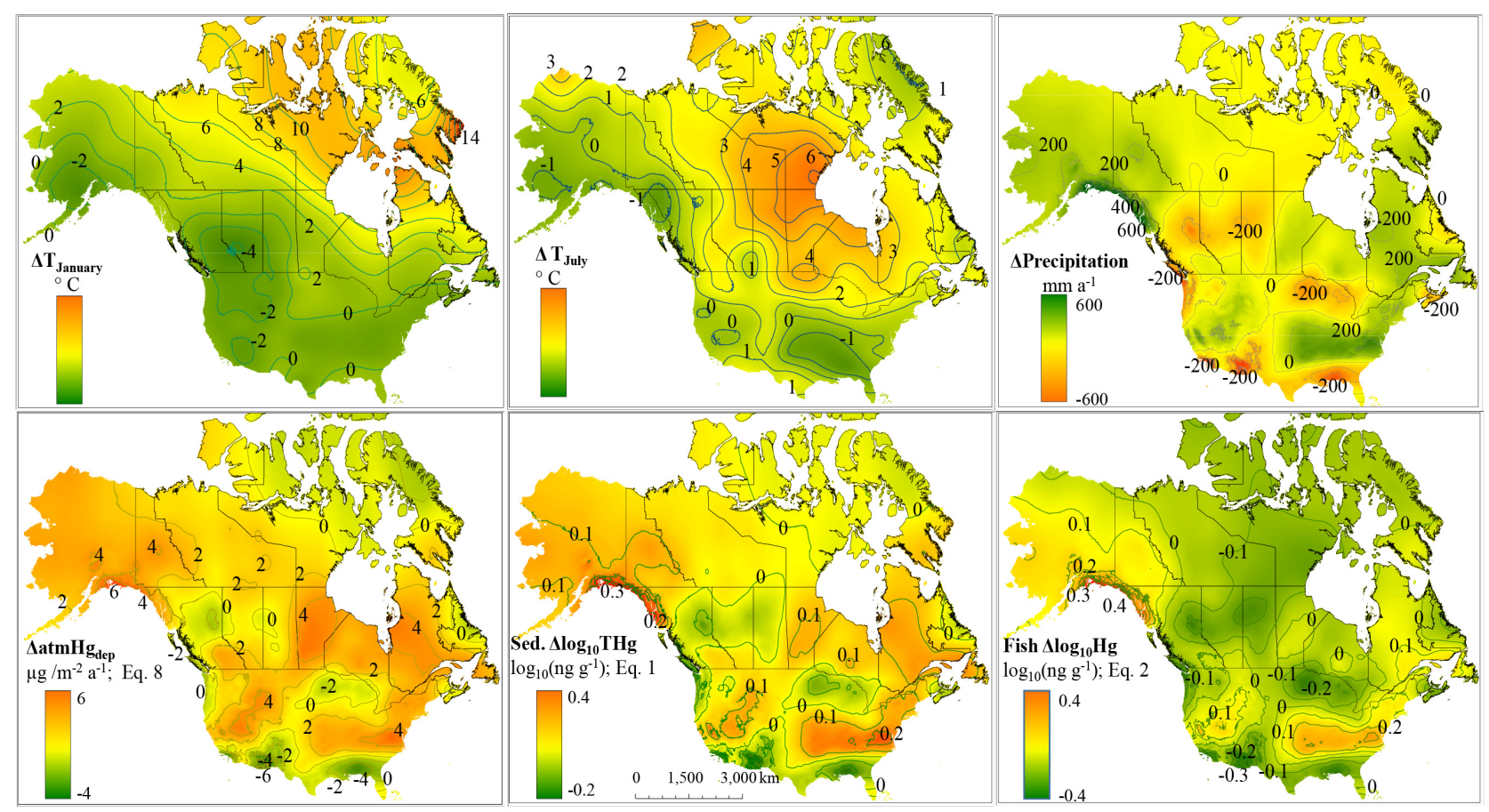

Figure 4. Projected 2011 to 2070 changes in mean annual January and July temperature $\left(\Delta \mathrm{T}_{\text {Jan }}, \Delta \mathrm{T}_{\text {July }}\right)$, mean annual precipitation $(\Delta \mathrm{ppt})$, net atmospheric $\mathrm{Hg}$ deposition $\left(\Delta \mathrm{atmHg}_{\mathrm{dep}}\right)$, Sediment $\mathrm{THg}\left(\Delta \log _{10} \mathrm{Hg}\right)$ and Fish $\mathrm{THg}\left(\Delta \log _{10} \mathrm{Hg}\right)$ including contoursas outlined across the Canada (except most northern parts) and the continental USA. 
influence on $\mathrm{Hg}$ methylization and fish uptake in the water column, trophic $\mathrm{Hg}$ uptake may also occur along biologically active and generally muddy top portions of lake sediments. However, the solid 30-cm deep cores of the GSC sediment survey represent about 100 years to sediment accumulation in northern lakes [52]. Hence, Sediment THg concentrations-as determined from the dried and ground-up sediment cores-would influence Fish $\mathrm{Hg}$ uptake only indirectly as a co-variate, with both Sediment THg and Fish THg influenced by external Hg lake inputs. In addition, while Equations (2) and (5) imply that Fish THg to Sediment THg co-vary to some extent across Canada, this is not necessarily the case within region-specific studies with limited range in climatic variations as noted for northern Ontario [53] and for the Great lakes region [54].

While atmospheric $\mathrm{Hg}$ emission and deposition rates have decreased over the last 25 years or so [55] [56], this is not reflected by the 1967-to-2010 FIMDAC data for which

Fish $\log _{10} \mathrm{THg}$

$=(1.78 \pm 0.01)+(0.0020 \pm 0.0005)$ Sampling year since 1970, $R^{2}=0.0047$

In part, this is due to increasing and decreasing trends by regions and lakes. In some areas, gradual declines in Fish THg have occurred [46]. Increases in Sediment THg with increasing atmTHg ${ }_{\text {dep }}$-as implied by Equations (4) and (5) - have been reported for the upper layer of non-bulked mid- to high-latitude lake sediments by [52] and [57]. Fish THg followed a straight-line downward pattern for Lake Ontario from 1998 to 2009. For Lake Superior and Erie, 1998-to-2009 Fish $\mathrm{THg}$ decreased and then increased again. For Lake Huron and Michigan, the opposite occurred [58].

Using Equations (1), (2), and (8) to estimate changes in atmHg $\mathrm{g}_{\text {dep }}$, Sediment THg and Fish THg into the future based on current 2011-2070 $\mathrm{T}_{\text {Jan }}$, $\mathrm{T}_{\text {July }}$ and mean annual precipitation projections produced the changes mapped in Figure 4 across Canada (except the northern most islands) and the continental USA. These maps suggest that-without further changes in anthropogenic Hg emission rates-Sediment THg and Fish THg would change up and down by at most a factor of 3 or 5 , respectively. At the same time, atmHg dep would change regionally from 4 to $6 \mu \mathrm{g} \cdot \mathrm{m}^{-2} \cdot \mathrm{a}^{-1}$, which corresponds to about $10 \%$ to $15 \%$ of the current total $\mathrm{Hg}$ deposition range across Canada and the USA. For the most part, the projected atmHg $\mathrm{dep}_{\text {, }}$ Sediment THg and Fish THg changes follow the projected precipitation pattern, being generally positive along the northern Pacific and mid-latitude Atlantic regions. Decreasing precipitation would lower atmHg $_{\text {dep }}$, Sediment THg and Fish THg along, e.g., the Bay of Mexico, the Prairie provinces of Canada (Alberta, Saskatchewan, Manitoba), and the States along the Bay of Mexico and along the Great Lakes.

Together, the Equation (2) projected changes for Fish THg in Figure 4 are relatively small except where precipitation levels would increase by $200 \mathrm{~mm}$ or more. The corresponding lack of major Fish THg changes-as represented by 
Equation (9) and in Figure 4-is likely due to a cancelling of positive and negative lake-by-lake trends. For example, [59] and [46] reported declining to non-declining levels of Fish $\mathrm{Hg}$ with respect to climate warming. In contrast, [60] 1) reported increasing Fish THg levels for Ontario, varying over the last 15 years from 0.01 to $0.16 \mu \mathrm{g} \cdot \mathrm{g}^{-1}$ per decade by fish species (4321 screened data), and 2) extrapolated these into the future, up to 2050.

Changing to non-changing levels in Fish THg are likely due to complex interactions involving changes in trophic $\mathrm{Hg}$ transferences, fish predation, lake-water conditions (temperature, aeration, chemical composition) and reductions in atmospheric and terrestrial Hg inputs into lakes. The latter, as implied by Equations (3) and (4), would especially be the case in areas subject to drought (i.e., low ppt, high rates of $\mathrm{Hg}$ volatilization, low rates of $\mathrm{Hg}$ immobilization). On land, $\mathrm{Hg}$ retention and land-to-lake transfers are affected by upslope land use, extent and type of vegetation type including wetland coverage, and Hg-containing mineral exposures [22] [61]. Increased surface temperatures on land stimulate 1) $\mathrm{Hg}$ re-volatilization from open areas [62], 2) $\mathrm{Hg}$ losses due to forest fires [63], and 3) $\mathrm{Hg}$ immobilization in vegetation biomass and in soil organic matter due to increased warmer and longer summer growth, especially where soils remain moist to wet [8] [64].

Increasing upstream lake-to-lake wetland coverage tends to increase $\mathrm{THg}$ in water and fish through brown-water transfer of organically complexed $\mathrm{Hg}$ [7] [65] [66]. In lakes, fish uptake of $\mathrm{Hg}$ varies by, e.g., extent and type of lake input from land and atmospheric sources, and by lake size and morphology. Daily, seasonal and annual water-intake and related aeration and de-aeration dynamics affect in-lake trophic bioaccumulation of methyl $\mathrm{Hg}$ directly [67]. For example, increased $\mathrm{Hg}$ uptake by fish would occur through increased net $\mathrm{Hg}$ methylization as hypolimnetic water temperatures and biological oxygen demands rise from cool to warm [68]. In this regard, brown-water discharge renders small lakes warmer than clear-water lakes, thereby reduxing epi- and hypolimnetic aeration which would stimulate $\mathrm{Hg}$ methylization. Hence, Fish THg (small brown-water lakes) > Fish THg (clear-water lakes). In addition, Fish $\mathrm{Hg}$ increases with decreasing lake-water $\mathrm{pH}$, likely due to higher levels of $\mathrm{Hg}$ solubility and increased $\mathrm{Hg}$ methylization rates at lower $\mathrm{pH}$ [68] [69]. However, Fish $\mathrm{THg}$ can also increase with increasing $\mathrm{pH}$, particular where in-lake de-aeration trumps the $\mathrm{pH}$ effect on $\mathrm{Hg}$ methylization [70] [71].

Detailed studies have shown that, while increasing water temperatures increase the production and uptake of methyl $\mathrm{Hg}$ from sediments and epilimnetic and anoxic hypolimnetic waters [72], there is also a concurrent temperature increase in Hg demethylation [53] [73]. [71] reported that deepening the thermocline and oxycline of one lake relative to a reference lake (done by way of pumping at about $15,000 \mathrm{~m}^{3} \cdot \mathrm{day}^{-1}$ ) increased epilimnetic temperature and oxygen saturation leading to continuing reductions in epilimnetic $\mathrm{MeHg}$ and Fish $\mathrm{THg}$, with post-experiment effects lasting for at least one year. Hence, future changes in Fish $\mathrm{Hg}$ are also related to climate-induced thermocline inversions, lake-by-lake. 
Across northern Canada, the influx of $\mathrm{Hg}$ and $\mathrm{MeHg}$ into lakes and rivers peaks during the snowmelt season, and is lowest during the winter season [74].

Post-2000 Sediment THg fluxes decreased towards northern latitudes after showing a steady increase since about 1900 . This was likely in response to the steadily falling of net atmospheric $\mathrm{Hg}$ deposition rates over the last 25 years [75] [76] [77]. Mercury levels in fish, birds, and mammals, however, varied, with inter-annual trends remaining uncertain across arctic inland and marine waters [5] [67] [78] [79]. In contrast, the subarctic region is currently subject to increasing permafrost decline. This decline produces water-filled collapse scars across peat plateaus [80], with each scar supporting algal growth, which in turn leads to peat-and mineral-released $\mathrm{Hg}$ accumulations in lakes and sediments [81] [82] [83].

Given that total $\mathrm{Hg}$ concentrations in retail fish should not exceed $500 \mathrm{ng} \cdot \mathrm{g}^{-1}$ [84] (which corresponds to $\log _{10} \mathrm{THg}=2.70$ ), most of the standardized Fish THg values fell below this limit. The percentage extent to this value to be exceeded in 2070 would mainly be limited to southern Quebec where the maximum projected change in $\log _{10} \mathrm{THg}$ is $\approx 0.1$, and more strongly so along the Pacific coast, where the maximum projected change in $\log _{10} \mathrm{THg}$ is $\approx 0.4$.

Altogether, $60 \%$ of the Fish THg variations remain unexplained by way of the above trend analysis. This situation may improve by adding lake-by-lake variables such as lake size, morphology, upland watershed, topography and upslope wetland coverage to the analysis.

\section{Concluding Remarks}

As shown, climate affects in-lake $\mathrm{Hg}$ accumulations due to variations in weather, season, atmospheric $\mathrm{Hg}$ deposition, surrounding vegetation, and geological $\mathrm{Hg}$ exposure patterns. This would also include lake-by-lake variations in thermocline inversion and related recovery times. As quantified above, cross-regional changes among the co-varying patterns of atmospheric $\mathrm{Hg}$ deposition, Sediment THg and Fish THg will likely remain small, with potential changes more likely related to changes in precipitation amounts, frequencies and intensities than to co-varying changes in atmospheric $\mathrm{Hg}$ deposition and temperature. A major exception to this would be occurring across the subarctic, where sustained permafrost losses lead to a widening incidence of peat-plateau scars followed by mineral- and peat-accumulated $\mathrm{Hg}$ release into lakes and rivers. In total, lake-by-lake variations in Fish THg will remain large as documented, and will require continued monitoring due to changing $\mathrm{Hg}$ inputs and changing in-lake dynamics.

Whether or not future levels in sediment and Fish THg will trend as projected in Figure 4 remains unknown. The assumption made is that the co-dependencies of the variables in Table 1 are functionally linked to changing climate variations not only across space, but also across time, in the same way.

\section{Acknowledgements}

We are grateful to the many Canadian organizations and researchers involved in 
the production and sharing of the data layers for Fish Hg, sediment Hg, atmospheric Hg deposition, and climate. We especially thank Linda Campbell (Saint Mary's University, Halifax), Neil M. Burgess and David Depew (Environment and Climate Change Canada) for helpful suggestions and comments.

\section{Conflicts of Interest}

The authors declare no conflicts of interest regarding the publication of this paper.

\section{References}

[1] Wente, S.P. (2004) A Statistical Model and National Data Set for Partitioning Fish-Tissue Mercury Concentration Variation between Spatiotemporal and Sample Characteristic Effects. US Geological Survey Scientific Investigation Report 2004-5199.

[2] USEPA (US Environmental Protection Agency) (2009) Mercury Environmental Effects. http://www.epa.gov/mercury/eco.htm

[3] Chen, C.Y., Borsuk, M.E., Bugge, D.M., Hollweg, T., Balcom, P.H., Ward, D.M., Williams, J. and Mason, R.P. (2014) Benthic and Pelagic Pathways of Methylmercury Bioaccumulation in Estuarine Food Webs of the Northeast United States. PLoS ONE, 9, e89305. https://doi.org/10.1371/journal.pone.0089305

[4] Wentz, D., Brigham, M., Chasar, L., Lutz, M. and Krabbenhoft, D. (2014) Mercury in the Nation's Streams-Levels, Trends, and Implications. US Geological Survey Circular 1395.

[5] Steffen, A. and Morrison, H. (2016) Canadian Mercury Science Assessment Report (CMSAR). Environment and Climate Change.

[6] Demers, J.D., Driscoll, C.T., Fahey, T.J. and Yavitti, J.B. (2007) Mercury Cycling in Litter and Soil in Different Forest Types in the Adirondack Region, New York, USA. Ecological Applications, 7, 1341-1351. https://doi.org/10.1890/06-1697.1

[7] Meng, F.R., Arp, P.A., Sangster, A., Brun, G.L., Rencz, A.N., Hall, G.E., Holmes, J., Lean, D.R.S. and Clair, T.A. (2005) Modeling Dissolved Organic Carbon, Total and Methyl Mercury in Kejimkujik Freshwaters. In: O’Driscoll, N.J., Rencz, A.N. and Lean, D.R.S., Eds., Mercury Cycling in a Wetland-Dominated Ecosystem: A Multidisciplinary Study, SETAC, Pensacola, 267-282.

[8] Grigal, D.F. (2002) Inputs and Outputs of Mercury from Terrestrial Watersheds: A Review. Environmental Reviews, 10, 1-39. https://doi.org/10.1139/a01-013

[9] Grigal, D.F. (2003) Mercury Sequestration in Forests and Peatlands. Journal of Environmental Quality, 32, 393-405. https://doi.org/10.2134/jeq2003.3930

[10] Nasr, M. and Arp, P.A. (2016) Biomonitoring and Assessing Total Mercury Concentrations and Pools in Forested Areas. Biomonitoring, 2, 47-63. https://doi.org/10.1515/bimo-2015-0008

[11] Nasr, M., Malloch, D.W. and Arp, P.A. (2012) Quantifying Hg within Ectomycorrhizal Fruiting Bodies, from Emergence to Senescence. Fungal Biology, 116, 1163-1177. https://doi.org/10.1016/j.funbio.2012.09.002

[12] Schuster, P.F., Shanley, J.B., Marvin-Dipasquale, M., Reddy, M.M., Aiken, G.R., Roth, D.A., Taylor, H.E., Krabbenhoft, D.P. and DeWild, J.F. (2008) Mercury and Organic Carbon Dynamics during Runoff Episodes from a Northeastern USA Watershed. Water, Air, and Soil Pollution, 187, 89-108.

https://doi.org/10.1007/s11270-007-9500-3 
[13] Sanei, H. and Goodarzi, F. (2006) Relationship between Organic Matter and Mercury in Recent Lake Sediment: The Physical-Geochemical Aspects. Applied Geochemistry, 21, 1900-1912. https://doi.org/10.1016/j.apgeochem.2006.08.015

[14] Ghorpade, S., Heyes, A., Gilmour, C.C. and Oswald, C.J. (2009) The Relationship between Dissolved Organic Carbon Quality and Mercury Transport in a Boreal Watershed. American Geophysical Union, Fall Meeting 2009, 14-18 December 2009, San Fransisco.

[15] Riscassi, A.L., Hokanson, K.J. and Scanlon, T.M. (2011) Streamwater Particulate Mercury and Suspended Sediment Dynamics in a Forested Headwater Catchment. Water, Air, and Soil Pollution, 220, 23-36. https://doi.org/10.1007/s11270-010-0731-3

[16] Zhang, X., Rygwelski, K.R., Kreis, R.G. and Rossmann, R. (2014) A Mercury Transport and Fate Model (LM2-Mercury) for Mass Budget Assessment of Mercury Cycling in Lake Michigan. Journal of Great Lakes Research, 40, 347-359. https://doi.org/10.1016/j.jglr.2014.03.008

[17] Jutras, M.-F., Nasr, M., Castonguay, M., Pit, C., Pomeroy, J.H., Smith, T.P., Zhang, C., Ritchie, C.D., Meng, F.-R., Clair, T.A. and Arp, P.A. (2011) Dissolved Organic Carbon Concentrations and Fluxes in Forest Catchments and Streams: DOC-3 Model. Ecological Modelling, 222, 2291-2313. https://doi.org/10.1016/j.ecolmodel.2011.03.035

[18] Teisserenc, R., Lucotte, M. and Houel, S. (2011) Terrestrial Organic Matter Biomarkers as Tracers of Hg Sources in Lake Sediments. Biogeochem, 103, 235-244. https://doi.org/10.1007/s10533-010-9458-x

[19] Demers, J.D., Driscoll, C.T. and Shanley, J.B. (2010) Mercury Mobilization and Episodic Stream Acidification during Snowmelt: Role of Hydrologic Flow Paths, Source Areas, and Supply of Dissolved Organic Carbon. Water Resources Research, 46, W01511. https://doi.org/10.1029/2008WR007021

[20] Mei, Y., Hornberger, G.M., Kaplan, L.A., Newbold, J.D. and Aufdenkampe, A.K. (2014) The Delivery of Dissolved Organic Carbon from a Forested Hillslope to a Headwater Stream in Southeastern Pennsylvania, USA. Water Resources Research, 50, 5774-5796. https://doi.org/10.1002/2014WR015635

[21] Dick, J.J., Tetzlaff, D., Birkel, C. and Soulsby, C. (2015) Modelling Landscape Controls on Dissolved Organic Carbon Sources and Fluxes to Streams. Biogeochemistry, 122, 361-374. https://doi.org/10.1007/s10533-014-0046-3

[22] Nasr, M. and Arp, P.A. (2017) Mercury and Organic Matter Concentrations in Lake and Stream Sediments in Relation to One Another and to Atmospheric Mercury Deposition and Climate Variations across Canada. Journal of Chemistry, 2017, Article ID: 8949502.

[23] Bengtsson, G. and Picado, F. (2008) Mercury Sorption to Sediments: Dependence on Grain Size, Dissolved Organic Carbon, and Suspended Bacteria. Chemosphere, 73, 526-531. https://doi.org/10.1016/j.chemosphere.2008.06.017

[24] Boszke, L., Kowalski, A., Glosińska, G., Szarek, R. and Siepak, J. (2003) Environmental Factors Affecting Speciation of Mercury in the Bottom Sediments; An Overview. Polish Journal of Environmental Studies, 12, 5-13.

[25] Ten Hulscher, T.E.M., Mol, G.A.J. and Luers, F. (1992) Release of Metals from Polluted Sediments in a Shallow Lake: Quantifying Resuspension. Hydrobiologia, 235/236, 97-105. https://doi.org/10.1007/BF00026203

[26] Hintelmann, H. and Harris, R. (2004) Application of Multiple Stable Mercury Isotopes to Determine the Adsorption and Desorption Dynamics of $\mathrm{Hg}$ (II) and $\mathrm{MeHg}$ 
to Sediments. Marine Chemistry, 90, 165-173.

https://doi.org/10.1016/j.marchem.2004.03.015

[27] O’Driscoll, N.J., Poissant, L., Canário, J., Ridal, J. and Lean, D.R.S. (2007) Continuous Analysis of Dissolved Gaseous Mercury and Mercury Volatilization in the upper St. Lawrence River: Exploring Temporal Relationships and UV Attenuation. Environmental Science \& Technology, 41, 5342-5348. https://doi.org/10.1021/es070147r

[28] Vaidya, O.C., Howell, G.D. and Leger, D.A. (1999) Evaluation of the Distribution of Mercury in Lakes in Nova Scotia and Newfoundland (Canada). Water, Air, \& Soil Pollution, 117, 353-369. https://doi.org/10.1023/A:1005190429095

[29] Chadwick, S.P., Babiarz, C.L., Hurley, J.P. and Armstrong, D.E. (2006) Influences of Iron, Manganese, and Dissolved Organic Carbon on the Hypolimnetic Cycling of Amended Mercury. Science of the Total Environment, 368, 177-188. https://doi.org/10.1016/j.scitotenv.2005.09.039

[30] Skyllberg, U. (2008) Competition among Thiols and Inorganic Sulfides and Polysulfides for $\mathrm{Hg}$ and $\mathrm{MeHg}$ in Wetland Soils and Sediments under Suboxic Conditions: Illumination of Controversies and Implications for MeHg Net Production. Journal of Geophysical Research: Biogeosciences, 113.

[31] El Bilali, L., Rasmussen, P.E., Hall, G.E.M. and Fortin, D. (2002) Role of Sediment Composition in Trace Metal Distribution in Lake Sediments. Applied Geochemistry, 17, 1171-1181. https://doi.org/10.1016/S0883-2927(01)00132-9

[32] Kainz, M., Lucotte, M. and Parrish, C.C. (2003) Relationships between Organic Matter Composition and Methyl Mercury Content of Offshore and Carbon-Rich Littoral Sediments in an Oligotrophic Lake. Canadian Journal of Fisheries and Aquatic Sciences, 60, 888-896. https://doi.org/10.1139/f03-075

[33] Kainz, M. and Lucotte, M. (2006) Mercury Concentrations in Lake Sediments-Revisiting the Predictive Power of Catchment Morphometry and Organic Matter Composition. Water, Air, \& Soil Pollution, 170, 173-189. https://doi.org/10.1007/s11270-006-3009-Z

[34] Neff, M.R., Bhavsar, S.P., Arhonditsis, G.B., Fletcher, R. and Jackson, D.A. (2012) Long-Term Changes in Fish Mercury Levels in the Historically Impacted English-Wabigoon River System (Canada). Journal of Environmental Monitoring, 14, 2327. https://doi.org/10.1039/c2em30324h

[35] Depew, D.C., Burgess, N.M., Anderson, M.R., Baker, R., Bhavsar, S.P., Bodaly, R.A., Eckley, C.S., Evans, M.S., Gantner, N., Graydon, J.A., Jacobs, K., LeBlanc, J.E., St. Louis, V.L. and Campbell, L.M. (2013) An Overview of Mercury Concentrations in Freshwater Fish Species: A National Fish Mercury Dataset for Canada. Canadian Journal of Fisheries and Aquatic Sciences, 70, 436-451.

https://doi.org/10.1139/cjfas-2012-0338

[36] Depew, D.C., Burgess, N.M. and Campbell, L.M. (2013) Modelling Mercury Concentrations in Prey Fish: Derivation of a National-Scale Common Indicator of Dietary Mercury Exposure for Piscivorous Fish and Wildlife. Environmental Pollution, 176, 234-243. https://doi.org/10.1016/j.envpol.2013.01.024

[37] Little, M., Burgess, N. and Campbell, L. (2014) Metadata: Fish Mercury Datalayer for Canada (FIDMAC).

[38] GSC Geological Survey of Canada, Natural Resources Canada (NRCan) (2008) Government of Canada. http://geochem.nrcan.gc.ca/cdogs/content/main/home_en.htm

[39] Friske, P.W.B. and Hornbrook, E.H.W. (1991) Canada's National Geochemical Re- 
connaissance Programme. Transactions of the Institution of Mining and Metallurgy, Section B, Applied Earth Science, 100, B47-B56.

[40] Nasr, M. (2015) Geospatial Analysis of Total Mercury Concentrations in Stream and Lake Sediments across Canada. Ph.D. Thesis, University of New Brunswick, Fredericton.

[41] (2017) Natural Resources Canada National Topographic System Index. http://www.nrcan.gc.ca/earth-sciences/geography/topographic-information/

[42] Dastoor, A.P. and Moran, M. (2010) Global/Regional Atmospheric Heavy Metals Model (GRAHM2005) Estimates of Atmospheric Mercury Deposition Rates at Sites in Northern Canada. Air Quality Research Division, Environment Canada.

[43] Meehl, G.A., Covey, C., McAveney, B., Latif, M. and Stouffer, R.J. (2005) Overview of the Coupled Model Intercomparison Project. The 2 nd CMIP Workshop, January 2005, 89-93.

[44] Kirk, L. (2006) Potential Sources of Monomethyl Mercury in Arctic and Subarctic Seawater. Essays in Information North, 59, 108-111.

[45] St Louis, V.L., Hintelmann, H., Graydon, J.A., Kirk, J.L., Barker, J., Dimock, B., Sharp, M.J. and Lehnherr, I. (2007) Methylated Mercury Species in Canadian High Arctic Marine Surface Waters and Snowpacks. Environmental Science \& Technology, 41, 6433-6441. https://doi.org/10.1021/es070692s

[46] Rennie, M.D., Sprules, W.G. and Vaillancourt, A. (2010) Changes in Fish Condition and Mercury Vary by Region, Not Bythotrephes Invasion: A Result of Climate Change? Ecography, 33, 471-482.

[47] Power, M., Klein, G.M., Guiguer, K.R.R.A. and Kwan, M.K.H. (2002) Mercury Accumulation in the Fish Community of a Sub-Arctic Lake in Relation to Trophic Position and Carbon Sources. Journal of Applied Ecology, 39, 819-830. https://doi.org/10.1046/j.1365-2664.2002.00758.x

[48] Risch, M.R., Dewild, J.F., Krabbenhoft, D.P., Kolka, R.K. and Zhang, L. (2012) Litterfall Mercury Dry Deposition in the Eastern USA. Environmental Pollution, 161, 284-290. https://doi.org/10.1016/j.envpol.2011.06.005

[49] Zhang, L., Blanchard, P., Gay, D.A., Prestbo, E.M., Risch, M.R., Johnson, D., Narayan, J., Zsolway, R., Holsen, T.M., Miller, E.K., Castro, M.S., Graydon, J.A., St. Louis, V.L. and Dalziel, J. (2012) Estimation of Speciated and Total Mercury Dry Deposition at Monitoring Locations in Eastern and Central North America. Atmospheric Chemistry and Physics, 12, 4327-4340. https://doi.org/10.5194/acp-12-4327-2012

[50] Wen, D. (2006) Modelling of Atmospheric Mercury Emission, Transport, Transformation and Deposition in North America. Ph.D. Thesis, University of Waterloo, Waterloo.

[51] Gbor, P.K., Wen, D., Meng, F., Yang, F. and Sloan, J.J. (2007) Modeling of Mercury Emission, Transport and Deposition in North America. Atmospheric Environment, 41, 1135-1149. https://doi.org/10.1016/j.atmosenv.2006.10.005

[52] Munthe, J., Wängberg, I., Rognerud, S., Fjeld, E., Verta, M., Porvari, P. and Meili, M. (2007) Mercury in Nordic Ecosystems. IVL Report B1761. IVL Swedish Environmental Research Institute Ltd., Göteborg.

[53] Bodaly, R.A., Rudd, J.W., Fudge, R.J. and Kelly, C.A. (1993) Mercury Concentrations in Fish Related to Size of Remote Canadian Shield Lakes. Canadian Journal of Fisheries and Aquatic Sciences, 50, 980-987. https://doi.org/10.1139/f93-113

[54] Sandheinrich, M.B., Bhavsar, S.P., Bodaly, R.A., Drevnick, P.E. and Paul, E.A. 
(2011) Ecological Risk of Methylmercury to Piscivorous Fish of the Great Lakes Region. Ecotoxicology, 20, 1577-1587. https://doi.org/10.1007/s10646-011-0712-3

[55] Butler, T.J., Cohen, M.D., Vermeylen, F.M., Likens, G.E., Schmeltz, D. and Artz, R.S. (2008) Regional Precipitation Mercury Trends in the Eastern USA, 1998-2005: Declines in the Northeast and Midwest, No Trend in the Southeast. Atmospheric Environment, 42, 1582-1592. https://doi.org/10.1016/j.atmosenv.2007.10.084

[56] Canada, E. (2014) Environment Canada's Mercury Website. http://www.ec.gc.ca/mercury/

[57] Muir, D.C., Wang, X., Yang, F., Jackson, T.A., Evans, M., Douglas, M., Köck, G., Pienitz, R., Smol, J.P., Vincent, W. and Lamoureux, S. (2009) Spatial Trends and Historical Inputs of Mercury and Lead in Eastern and Northern Canada Inferred from Lake Sediment Cores. Environmental Science \& Technology, 43, in Press. https://doi.org/10.1021/es8035412

[58] Zananski, T.J., Holsen, T.M., Hopke, P.K. and Crimmins, B.S. (2011) Mercury Temporal Trends in Top Predator Fish of the Laurentian Great Lakes. Ecotoxicology, 20, 1568-1576. https://doi.org/10.1007/s10646-011-0751-9

[59] French, T.D., Campbell, L.M., Jackson, D.A., Casselman, J.M., Scheider, W.A. and Hayton, A. (2006) Long-Term Changes in Legacy Trace Organic Contaminants and Mercury in Lake Ontario Salmon in Relation to Source Controls, Trophodynamics, and Climatic Variability. Limnology and Oceanography, 51, 2794-2807. https://doi.org/10.4319/lo.2006.51.6.2794

[60] Gandhi, N., Bhavsar, S.P., Tang, R.W.K. and Arhonditsis, G.B. (2015) Projecting Fish Mercury Levels in the Province of Ontario, Canada and the Implications for Fish and Human Health. Environmental Science \& Technology, 49, 14494-14502. https://doi.org/10.1021/acs.est.5b03943

[61] Hammerschmidt, C.R., Fitzgerald, W.F., Lamborg, C.H., Balcom, P.H. and Tseng, C.M. (2006) Biogeochemical Cycling of Methylmercury in Lakes and Tundra Watersheds of Arctic Alaska. Environmental Science \& Technology, 40, 1204-1211. https://doi.org/10.1021/es051322b

[62] Song, X. and Van Heyst, B. (2005) Volatilization of Mercury from Soils in Response to Simulated Precipitation. Atmospheric Environment, 39, 7494-7505. https://doi.org/10.1016/j.atmosenv.2005.07.064

[63] De Foy, B., Wiedinmyer, C. and Schauer, J.J. (2012) Estimation of Mercury Emissions from Forest Fires, Lakes, Regional and Local Sources Using Measurements in Milwaukee and an Inverse Method. Atmospheric Chemistry and Physics, 12, 8993-9011. https://doi.org/10.5194/acp-12-8993-2012

[64] Mason, R.P., Abbott, M.L., Bodaly, R.A., Bullock, R., Driscoll, C.T., Evers, D.C., Lindberg, S.E., Murray, M. and Swain, E.B. (2005) Monitoring the Response to Changing Mercury Deposition. Environmental Science \& Technology, 39, 15A-22A. https://doi.org/10.1021/es0531551

[65] Berndt, M.E. and Bavin, T.K. (2012) Methylmercury and Dissolved Organic Carbon Relationships in a Wetland-Rich Watershed Impacted by Elevated Sulfate from Mining. Environmental Pollution, 161, 321-327.

https://doi.org/10.1016/j.envpol.2011.06.006

[66] Driscoll, C.T., Blette, V., Yan, C., Schofield, C.L., Munson, R. and Holsapple, J. (1995) The Role of Dissolved Organic Carbon in the Chemistry and Bioavailability of Mercury in Remote Adirondack Lakes. Water, Air, \& Soil Pollution, 80, 499-508. https://doi.org/10.1007/BF01189700

[67] Chételat, J., Amyot, M., Arp, P., Blais, J.M., Depew, D., Emmerton, C.A., Evans, M., 
Gamberg, M., Gantner, N., Girard, C., Graydon, J., Kirk, J., Lean, D., Lehnherr, I., Muir, D., Nasr, M., Poulain, A.J., Power, M., Roach, P., Stern, G., Swanson, H. and van der Velden, S. (2015) Mercury in Freshwater Ecosystems of the Canadian Arctic: Recent Advances on Its Cycling and Fate. Science of the Total Environment, 509-510, 41-66. https://doi.org/10.1016/j.scitotenv.2014.05.151

[68] Greenfield, B.K., Hrabik, T.R., Harvey, C.J. and Carpenter, S.R. (2001) Predicting Mercury Levels in Yellow Perch: Use of Water Chemistry, Trophic Ecology, and Spatial Traits. Canadian Journal of Fisheries and Aquatic Sciences, 58, 1419-1429. https://doi.org/10.1139/f01-088

[69] Brown, A., Goncharov, A.B., Paul, E., Simonin, H.A. and Carpenter, D.O. (2010) The Relationship between Adirondack Lake $\mathrm{pH}$ and Levels of Mercury in Yellow Perch. Journal of Aquatic Animal Health, 22, 280-290.

https://doi.org/10.1577/H10-005.1

[70] Wyn, B., Kidd, K.A., Burgess, N.M., Curry, R.A. and Munkittrick, K.R. (2010) Increasing Mercury in Yellow Perch at a Hotspot in Atlantic Canada, Kejimkujik National Park. Environmental Science \& Technology, 44, 9176-9181. https://doi.org/10.1021/es1018114

[71] Rask, M., Verta, M., Korhonen, M., Salo, S., Forsius, M., Arvola, L., Jones, R.I. and Kiljunen, M. (2010) Does Lake Thermocline Depth Affect Methyl Mercury Concentrations in Fish? Biogeochemistry, 101, 311-322. https://doi.org/10.1007/s10533-010-9487-5

[72] Watras, C.J., Morrison, K.A., Kent, A., Price, N., Regnell, O., Eckley, C., Hintelmann, H. and Hubacher, T. (2005) Sources of Methylmercury to a Wetland-Dominated Lake in Northern Wisconsin. Environmental Science \& Technology, 39, 4747-4758. https://doi.org/10.1021/es040561g

[73] Trudel, M. and Rasmussen, J.B. (1997) Modeling the Elimination of Mercury by Fish. Environmental Science \& Technology, 31, 1716-1722. https://doi.org/10.1021/es960609t

[74] Loseto, L., Lean, D. and Siciliano, S.D. (2004) Snowmelt Sources of Methylmercury to High Arctic Ecosystems. Environmental Science and Technology, 38, 3004-3010. https://doi.org/10.1021/es035146n

[75] Cole, A.S., Steffen, A., Pfaffhuber, K.A., Berg, T., Pilote, M., Poissant, L., Tordon, R. and Hung, H. (2013) Ten-Year Trends of Atmospheric Mercury in the High Arctic Compared to Canadian Sub-Arctic and Mid-Latitude Sites. Atmospheric Chemistry and Physics, 13, 1535-1545. https://doi.org/10.5194/acp-13-1535-2013

[76] Cole, A.S., Steffen, A., Eckley, C.S., Narayan, J., Pilote, M., Tordon, R., Graydon, J.A., St. Louis, V.L., Xu, X. and Branfireun, B.A. (2014) A Survey of Mercury in Air and Precipitation across Canada: Patterns and Trends. Atmosphere (Basel), 5, 635-668. https://doi.org/10.3390/atmos5030635

[77] Weiss-Penzias, P.S., Gay, D.A., Brigham, M.E., Parsons, M.T., Gustin, M.S. and ter Schure, A. (2016) Trends in Mercury Wet Deposition and Mercury Air Concentrations across the U.S. and Canada. Science of the Total Environment, 568, 546-556. https://doi.org/10.1016/j.scitotenv.2016.01.061

[78] Braune, B., Chételat, J., Amyot, M., Brown, T., Clayden, M., Evans, M., Fisk, A., Gaden, A., Girard, C., Hare, A., Kirk, J., Lehnherr, I., Letcher, R., Loseto, L., Macdonald, R., Mann, E., McMeans, B., Muir, D., O’Driscoll, N., Poulain, A., Reimer, K. and Stern, G. (2015) Mercury in the Marine Environment of the Canadian Arctic: Review of Recent Findings. Science of the Total Environment, 509-510, 67-90. https://doi.org/10.1016/j.scitotenv.2014.05.133 
[79] Sundseth, K., Pacyna, J.M., Banel, A., Pacyna, E.G. and Rautio, A. (2015) Climate Change Impacts on Environmental and Human Exposure to Mercury in the Arctic. International Journal of Environmental Research and Public Health, 12, 3579-3599. https://doi.org/10.3390/ijerph120403579

[80] Jones, M.-F., Castonguay, M., Nasr, M., Ogilvie, J., Arp, P.A. and Bhatti, J. (2014) Modeling Hydrothermal Regimes and Potential Impacts of Climate Change on Permafrost within the South Mackenzie Plain, Northwest Territories, Canada. Écoscience, 21, 21-33. https://doi.org/10.2980/21-1-3663

[81] Kainz, M. and Mazumder, A. (2005) Effect of Algal and Bacterial Diet on Methyl Mercury Concentrations in Zooplankton. Environmental Science \& Technology, 39, 1666-1672. https://doi.org/10.1021/es049119o

[82] Carrie, J., Stern, G.A., Sanei, H., Macdonald, R.W. and Wang, F. (2012) Determination of Mercury Biogeochemical Fluxes in the Remote Mackenzie River Basin, Northwest Canada, Using Speciation of Sulfur and Organic Carbon. Applied Geochemistry, 27, 815-824. https://doi.org/10.1016/j.apgeochem.2012.01.018

[83] MacMillan, G.A., Girard, C., Chételat, J., Laurion, I. and Amyot, M. (2015) High Methylmercury in Arctic and Subarctic Ponds Is Related to Nutrient Levels in the Warming Eastern Canadian Arctic. Environmental Science \& Technology, 49, 7743-7753. https://doi.org/10.1021/acs.est.5b00763

[84] Government of Canada. Mercury in Fish-Questions and Answers. https://www.canada.ca/en/health-canada/services/food-nutrition/food-safety/chemi cal-contaminants/environmental-contaminants/mercury/mercury-fish-questions-a nswers.html 